University of Nebraska - Lincoln

DigitalCommons@University of Nebraska - Lincoln

Papers in the Earth and Atmospheric Sciences

Earth and Atmospheric Sciences, Department

$12-16-2002$

\title{
Lake-catchment interactions with climate in the low Arctic of southern West Greenland
}

\author{
N. John Anderson \\ Geological Survey of Denmark and Greenland, N.J.Anderson@lboro.ac.uk \\ Sherilyn C. Fritz \\ University of Nebraska-Lincoln, sfritz2@unl.edu \\ Christopher E. Gibson \\ Department of Agriculture and Rural Development, Agricultural and Environmental Science Division, \\ Newforge Lane, Belfast \\ Bent Hasholt \\ University of Copenhagen, Øster Voldgade 10, DK-1350 Copenhagen K, Denmark \\ Melanie J. Leng \\ NERC Isotope Geoscience Laboratory, British Geological Survey, Keyworth, Nottingham, NG12 5GG, UK
}

Follow this and additional works at: https://digitalcommons.unl.edu/geosciencefacpub

Part of the Earth Sciences Commons

Anderson, N. John; Fritz, Sherilyn C.; Gibson, Christopher E.; Hasholt, Bent; and Leng, Melanie J., "Lakecatchment interactions with climate in the low Arctic of southern West Greenland" (2002). Papers in the Earth and Atmospheric Sciences. 22.

https://digitalcommons.unl.edu/geosciencefacpub/22

This Article is brought to you for free and open access by the Earth and Atmospheric Sciences, Department of at DigitalCommons@University of Nebraska - Lincoln. It has been accepted for inclusion in Papers in the Earth and Atmospheric Sciences by an authorized administrator of DigitalCommons@University of Nebraska - Lincoln. 


\title{
Lake-catchment interactions with climate in the low Arctic of southern West Greenland
}

\author{
N. John Anderson, Sherilyn C. Fritz, Christopher E. Gibson, Bent Hasholt and Melanie J. Leng
}

Arctic hydrology plays a central role in the earth's heat balance and ocean circulation (Vörösmarty et al. 2001). Future changes associated with human influence on the climate system are also predicted to cause major changes in the energy and hydrologic mass balance of Arctic catchments. Climate change will likely affect permafrost and snowmelt, which dominate Arctic hydrology and control the chemistry of surface runoff (and hence streams and lakes) as water percolates through the active layer. However, the controls and dynamic impact of snowmelt are poorly understood, because this critical timeframe is often missed by sampling programmes. In the Søndre Strømfjord area only the broad- est aspects of hydrologic variability have so far been documented (Hasholt \& Søgaard 1976).

Lakes respond to climatic forcing at a variety of timescales. For example, at relatively high frequencies (days), thermal stratification can be weakened or broken down by increased wind speeds associated with the passage of frontal systems. Seasonally, lake temperatures reflect annual changes in radiative heating and ambient air temperatures (Hostetler 1995). Year to year variability in climate can reduce the ice-free period (Magnuson et al. 2000; Doran et al. 2002). Over the longer term, (i.e. Holocene, hundreds to thousands of years) changes in the hydrological mass balance of

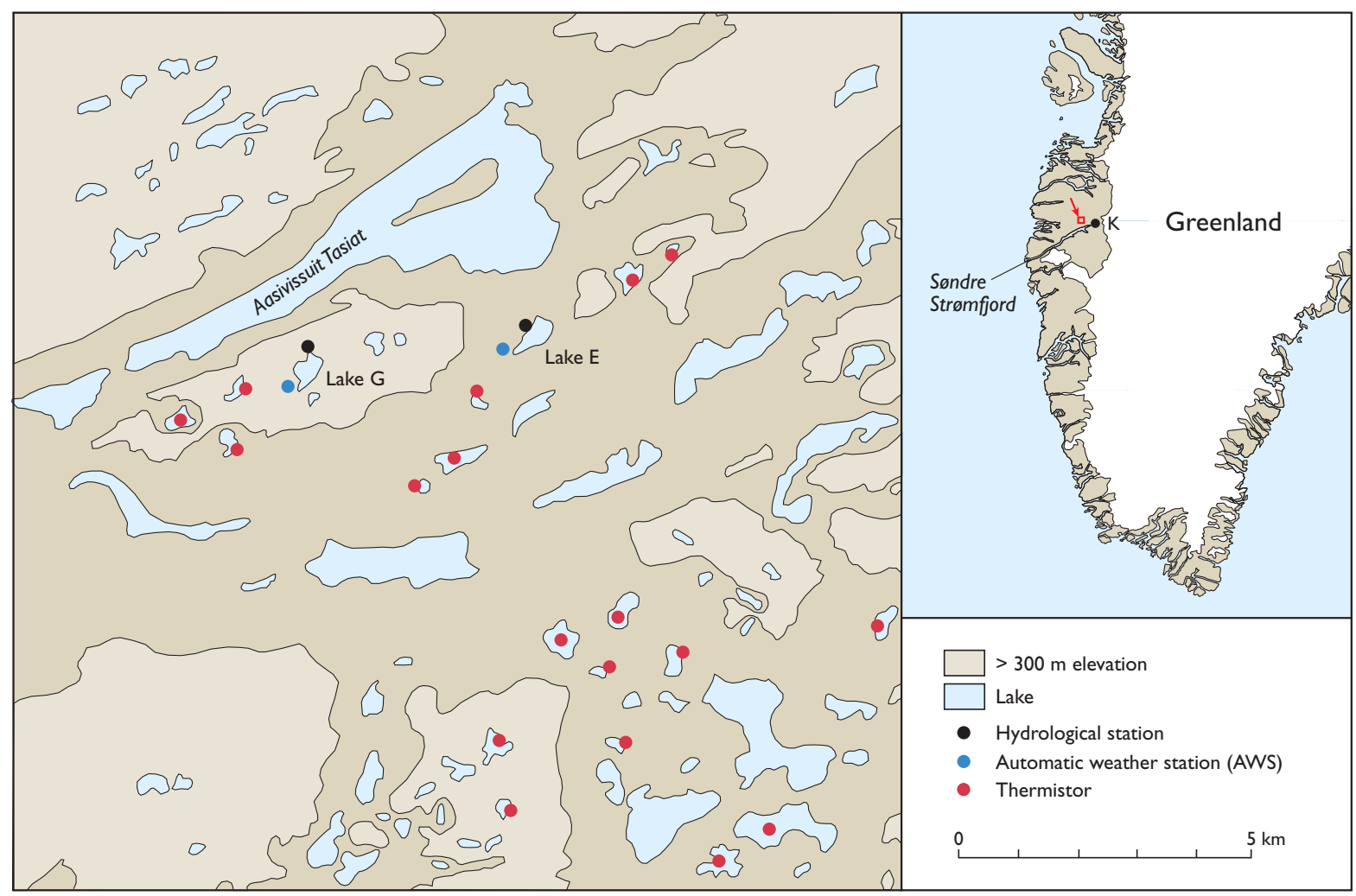

Fig. 1. Location map showing study area with hydrological monitoring stations, automatic weather stations and lakes with thermistor chains. K: Kangerlussuaq. 
lakes reflect hemispheric changes in climate systems and regional precipitation patterns (Overpeck et al. 1997). Some of these processes can be recorded in lake sediments, but it is clear that a better understanding of contemporary processes is crucial for interpreting sediment records unambiguously in terms of climate change.

The area of southern West Greenland between $66^{\circ} \mathrm{N}$ and $68^{\circ} \mathrm{N}$ contains approximately 20000 lakes. There is a strong climatic gradient between the Inland Ice margin and the coast. The zone immediately adjacent to the ice sheet is continental with low precipitation $(<170 \mathrm{~mm})$ and a mean annual temperature of $-6^{\circ} \mathrm{C}$. The coastal zone has a reduced annual temperature range and considerably greater annual precipitation; the summers are cooler, fog is common, and snow packs remain late into July. In contrast, closer to the ice sheet, summers are warmer and drier. Not surprisingly, the limnology of lakes in this area reflects this strong gradient. Lakes at the coast tend to be dilute and oligotrophic, whereas closer to the head of Søndre Strømfjord (Fig. 1), where evaporation exceeds precipitation on an annual basis, many of the closed basin lakes have become 'saline' due to long-term evaporation. Catchments close to the head of the fjord are characterised by minimal surface runoff during the summer - most runoff is via the active layer and occurs during the spring thaw. There are often large areas of bare rock, as well as aeolian deposits (often on the drier, southfacing slopes), and the more luxuriant vegetation is associated with damper hollows and lake outflows (Fig. 2).
Initially, our work in southern West Greenland had the aim of using the oligosaline lakes as archives of past changes in effective precipitation. Work to date has primarily been concerned with sediment core studies and long-term climate change (Anderson \& Bennike 1997; Anderson et al. 2000). More recently, however, field activity has concentrated on two main aspects of the interaction of lakes with local and regional climatic variability: namely, timing of icemelt and patterns of thermal stratification (Anderson \& Brodersen 2001). However, a more complete understanding of the hydrological links between lakes, local climate as well as their catchments is still lacking, and the rationale for the present project was therefore to combine these varying interactions in a more holistic manner.

\section{Aims of the present project}

In an attempt to integrate some of the contrasting but complementary aspects of lake-climate-catchment interactions in West Greenland, it was decided to focus specifically on a limited number of lakes and their catchment hydrology. Two neighbouring lakes were chosen, one with an outflow and one without, but both experiencing a similar regional climate and having similar geology and vegetation. The aim is an integrated study that combines an energy and hydrological mass balance of two contrasting lake catchments with measurements of contemporary and long-term sedimentation in the
Fig. 2. The hydrological station at the outflow from Lake $\mathrm{G}$ in August. The more extensive vegetation growth is apparent despite there being no flow from the lake.

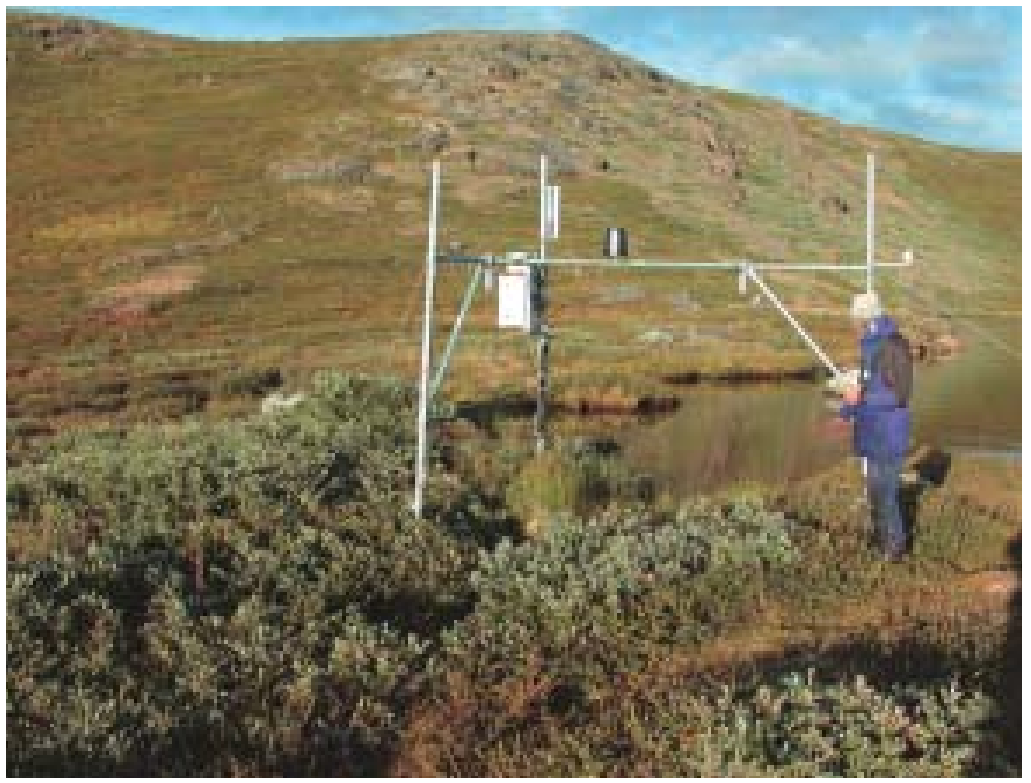


lakes. As in earlier reports (e.g. Anderson \& Brodersen 2001), we here follow the convention of referring to the fjord as Søndre Strømfjord and the airport at the head of the fjord as Kangerlussuaq (Fig. 1).

\section{Study sites}

Field activity during 2001 was concentrated on two lakes - E and G (Fig. 1) that were identified as possible study sites during field work in May 2000 (Bindler et al. 2001). The lakes have contrasting water chemistry and are reasonably representative of the type of lakes that occur close to the head of Søndre Strømfjord
(Anderson et al. 2001). Lake $\mathrm{E}$ is a closed-basin lake (mean conductivity is $3000 \mu \mathrm{S} \mathrm{cm}{ }^{-1}$ ) and is surrounded by extensive fossil shorelines (Fig. 3). In contrast, Lake $\mathrm{G}$ has an outflow (and consequently lower conductivity, $220 \mu \mathrm{S} \mathrm{cm}^{-1}$ ) that drains the lake on the north side, flowing via two small ponds and a wetland area (Fig. 4) into Aasivissuit Tasiat (see Fig. 1).

\section{Field work in 2001}

Field work was conducted during three periods: late April to early May, June and August. The initial field work undertaken in late April - early May used the ice cover
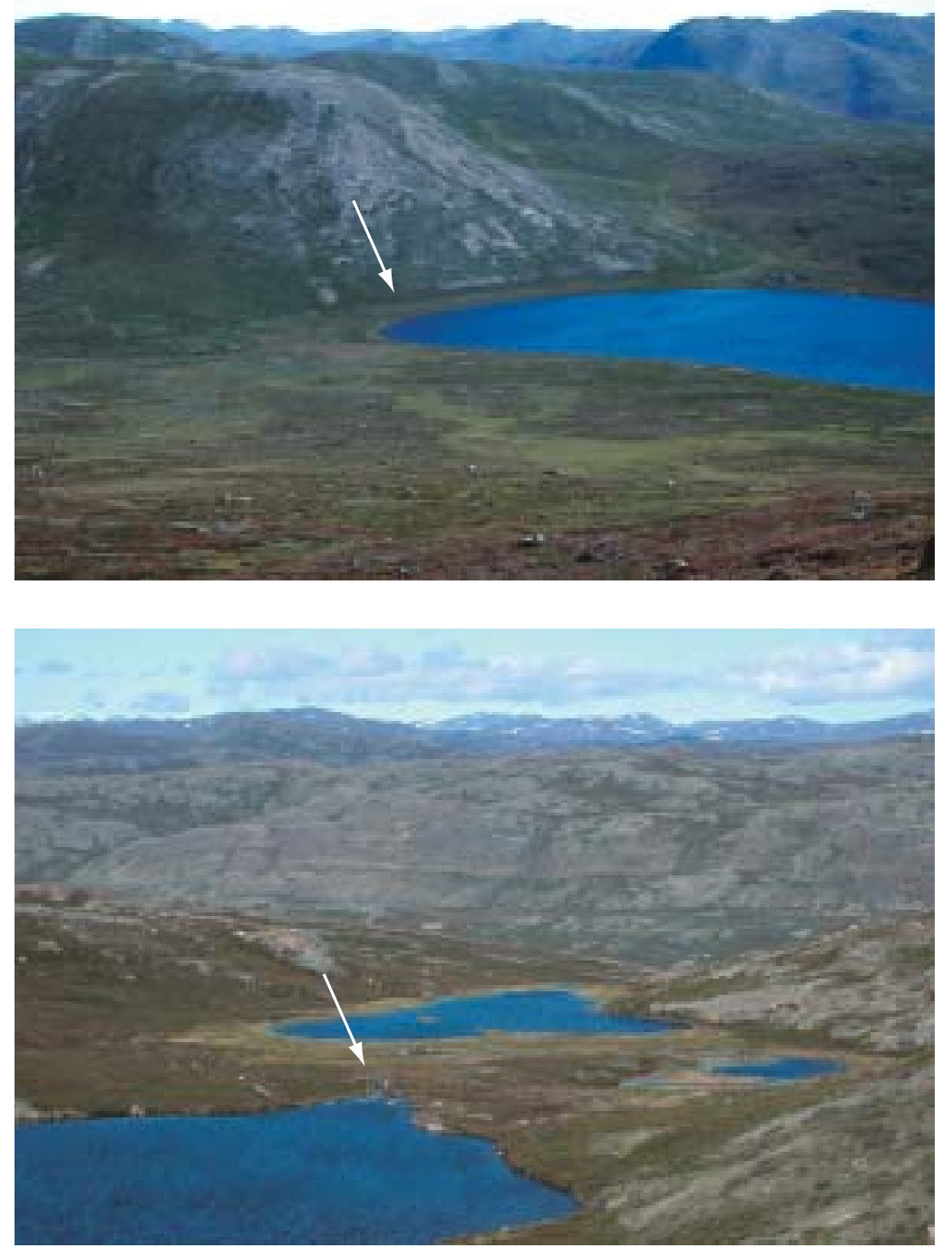

Fig. 3. Looking down on Lake E. The fossil shoreline development on the far (north-eastern) shore is clear. The upper limit of the shoreline is approximately $7 \mathrm{~m}$ above present lake level (arrowed). Width of the lake is c. $500 \mathrm{~m}$.
Fig. 4. The outflow from lake G, showing the two ponds and associated wetland areas. The hydrological station, which is just visible (arrowed), provides scale. The lake in the centre of the view is approximately $100 \mathrm{~m}$ across. 
on the lakes as a platform for retrieving sediment cores ('Russian' and freeze cores) from both lakes (see Anderson et al. 2000 for a description of field methods). At the same time, sediment traps and strings of temperature thermistors were also deployed (Anderson \& Brodersen 2001). Both lakes have laminated sediments, although the quality of laminations at Lake E deteriorates with sediment depth. Lake G, however, is characterised by fine, calcite laminated sediments throughout its length.

The Technicap sediment traps ( $\sim 1 \mathrm{~m}$ high and approximately $25 \mathrm{~kg}$ in weight; Fig. 5A) were dropped through the ice, with the major buoyancy floats at a depth of $3 \mathrm{~m}$ to avoid being caught in the ice. The traps, which are fully automatic with a motorised carousel and 12 collecting bottles (Fig. 5B), were programmed to change bottles every 18 days.

The hydrological monitoring of the lakes forms an important component of the present project. In establishing the hydrological stations prior to the start of the spring thaw, it was hoped that the changes in flow and lake level associated with this critical period could be recorded. The hydrological stations, which are based on a sturdy V-shaped frame (Fig. 2), include a variety of sensors (precipitation, pressure transducers for lake level, snow depth, soil temperature, stream flow) and a Campbell Scientific CR10X data logger. At Lake G the station was set up over the outflow. At Lake E, where there is no outflow, the station was located on the western shore, straddling the lake margin. In conjunction with the hydrological station at Lake E, a new automatic weather station (AWS) was set up at the southern end of the lake. As well as standard temperature and wind monitors, this station also included a full suite of radiation sensors, a soil heat-flux sensor and soil temperature recorders. Finally, an initial snow taxation (snow depth and density) was made for both catchments. Field activity in June included a detailed mapping of the catchments using a Trimble 4000SE base station with two roving systems (a Trimble 4000SE and a Trimble Pathfinder) differentially corrected against the base station. A Topcon GTS- 6 was used for more accurate surveying of the terrain immediately surrounding the lake shorelines. This surveying was to enable the development of a digital terrain model for each catchment. Lake bathymetric surveys were also undertaken.

In an effort to determine sediment transport within the catchment, a number of simple sediment traps were set out to determine surface transport and atmospheric inputs to the lakes. The hydrological stations were checked in June, and those sensors that could not be
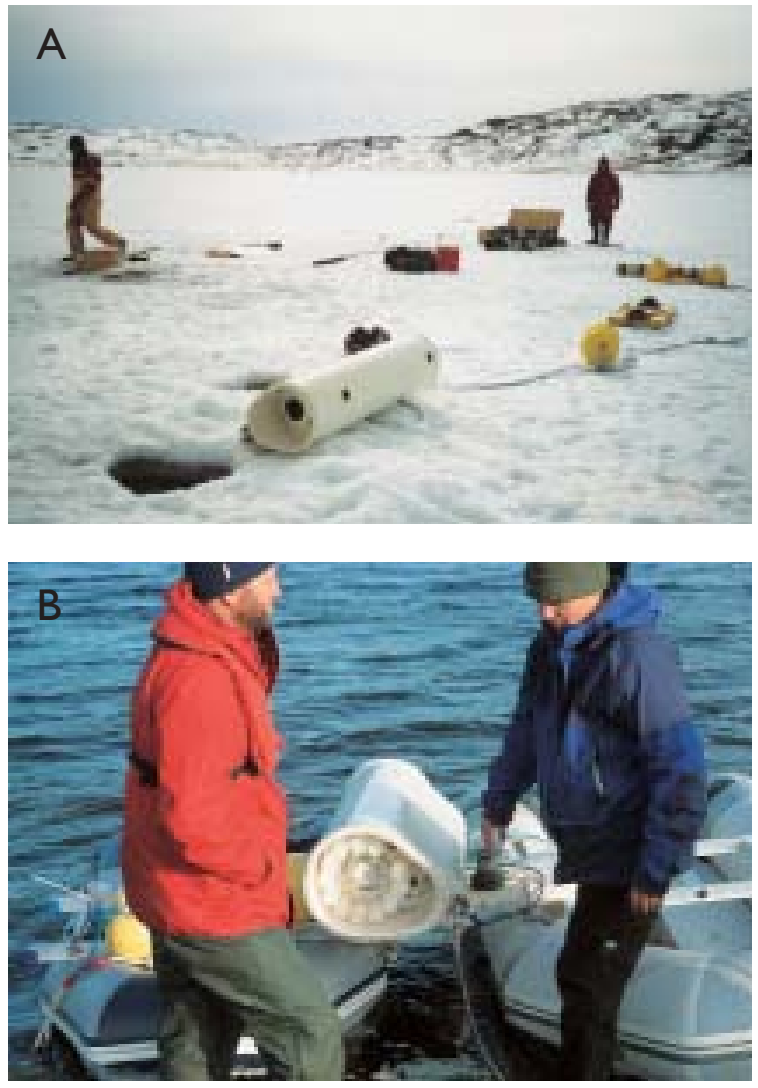

Fig. 5. A: A Technicap sediment trap on the ice at Lake E prior to deployment; 26 April 2001. B: A sediment trap lying on the improvised raft prior to redeployment in August 2001; the collecting bottles are clearly visible.

deployed in April were put out in the lakes. An AWS previously located halfway to the coast was upgraded and moved to the shore of Lake G. Individual temperature thermistors were put in 15 additional lakes around the two detailed study sites. These continuous measurements will provide a detailed record of the variability of icemelt (in spring 2002) and summer temperatures (for both 2001 and 2002) for a specific area, with good meteorological control provided by the two AWSs.

In August, the sediment traps were emptied, and the carousels changed and re-programmed for the next 12 months. Temperature thermistors were relocated to the central deepest part of each lake on metal wires to increase their chance of surviving the winter. On all three visits during the year, samples were taken for chemical and isotope analyses of surface water, together with water-column profiling of oxygen, temperature and conductivity. 


\section{Discussion}

Global climate models predict considerable future change in the Arctic, although response will not be uniform. This variability is clear from a synthesis of longterm monitoring data, which shows that around Søndre Strømfjord temperature has declined in the period 1970-2000 (Serreze et al. 2000). Future predicted changes include altered mass and energy inputs, with resultant increased precipitation in some areas and decreases in others. However, our understanding of the hydrological cycle in the Arctic is characterised by a relatively sparse observational network, and the length of monitoring records is often very short and sporadic. Hence it is difficult to detect trends and identify abnormal years.

Although our contemporary monitoring programme is located in a crucial area of the Arctic, where present hydrological information is limited, by necessity it will provide only a short-term view of environmental variation. Our aim, however, is to use this contemporary hydrological and meteorological data to calibrate longterm lake response. High-resolution sediment core studies can then be used to identify decadal trends in lake water conductivity. These core records can be coupled with energy-balance models derived from modern hydrological data to estimate the past climate conditions that were required to produce the past lake level (and lake water conductivity) changes. The objective of the present project, therefore, is to integrate, as far as possible across a range of temporal scales, longer-term (102-103 years) to short-term (i.e. seasonal) processes. In a multidisciplinary approach to palaeoenvironmental reconstruction, it is also planned to couple geomorphic studies of large-scale landscape features, such as palaeoshorelines and terraces, with the finer scale record embedded in the sediment cores.

Previously, a number of lake sites with finely laminated sediments have been recorded (Anderson et al. 1999). Although they are not annual (i.e. varves), the palaeoenvironmental significance of the changing structure of these laminations is considerable, if the dominant processes and frequency can be determined. Some of the structure can be readily interpreted, for example calcite precipitation and deposition of purple sulphur bacteria form unambiguous laminations. It is unknown, however, whether calcite precipitation in these lakes occurs under ice (due to salinisation effects associated with salt expulsion from ice) or during the summer due to photosynthesis (increasing $\mathrm{pH}$ ), or how often this occurs. The processes underlying the inter- play of other organic/inorganic fractions are even less clear. The Technicap sediment traps were originally developed for the marine environment but are ideally suited to remote Arctic lakes where regular emptying is problematical. Aspects of our catchment studies are aimed at determining how much minerogenic matter is derived from the catchment, as many of the lakes around the head of Søndre Strømfjord lack discrete inflows. The amount of material brought in during the spring thaw is also unknown. Thus the sediment traps will allow us to couple the lake sediment record with the climatic/meteorological processes giving rise to the sediment flux, both from the catchment and within the lake.

\section{Conclusion}

Understanding future changes in the hydrology of Arctic catchments will be difficult, because of the paucity of contemporary data. Similarly, our interpretation of past changes in the hydrological mass balance of lakes and catchments, as exemplified by fossil shorelines in the Søndre Strømfjord area, can only be strengthened by understanding contemporary processes. Combined with hydrologic mass balances and an assessment of the geomorphic setting, we aim to quantify seasonal sediment input through the use of sediment cores and sediment traps. These historical scenarios and the associated palaeoclimatic inferences can then be validated by lake energy balance models (Hostetler 1995).

\section{Acknowledgements}

The field work was undertaken with financial support from the Danish Natural Science Research Council (SNF), National Science Foundation (NSF, USA) and the European Commission (EMERGE). Assistance in the field was provided by William Clarke (Department of Agriculture Northern Ireland, UK), Ulf Thomas, Marianne Grauert, Mikael Kamp-Sørensen, Kim Edmunds (all University of Copenhagen) and Neil Rose, Simon Patrick, Sergi Pla, Chris Curtis, Mike Hughes and Martin Kernan (all University College London, UK).

\section{References}

Anderson, N.J. \& Bennike, O. 1997: Holocene lake sediments in West Greenland and their palaeoclimatic and palaeoecological implications. Geology of Greenland Survey Bulletin 176, 89-94. 
Anderson, N.J. \& Brodersen, K.P. 2001: Determining the date of ice-melt for low Arctic lakes along Søndre Strømfjord, southern West Greenland. Geology of Greenland Survey Bulletin 189, 54-58.

Anderson, N.J., Bennike, O., Christofferson, K., Jeppesen, E., Markager, S., Miller, G. \& Renberg, I. 1999: Limnological and palaeolimnological studies of lakes in south-western Greenland. Geology of Greenland Survey Bulletin 183, 68-74.

Anderson, N.J., Clarke, A., Juhler, R.K., McGowan, S. \& Renberg, I. 2000: Coring of laminated lake sediments for pigment and mineral magnetic analyses, Søndre Strømfjord, southern West Greenland. Geology of Greenland Survey Bulletin 186, 83-87.

Anderson, N.J., Harriman, R., Ryves, D.B. \& Patrick, S.T. 2001: Dominant factors controlling variability in the ionic composition of West Greenland lakes. Arctic, Antarctic \& Alpine Research 33, 418-425.

Bindler, R., Anderson, N.J., Renberg, I. \& Malmquist, C. 2001: Palaeolimnological investigation of atmospheric pollution in the Søndre Strømfjord region, southern West Greenland: accumulation rates and spatial patterns. Geology of Greenland Survey Bulletin 189, 48-53.

Doran, P.T. et al. 2002: Antarctic climate cooling and terrestrial ecosystem response. Nature $\mathbf{4 1 5}, 517-520$.
Hasholt, B. \& Søgaard, H. 1976: Et forsøg på en klimatisk-hydrologisk regionsinddeling af Holsteinsborg Kommune (Sisimiut). Geografisk Tidsskrift 77, 72-92.

Hostetler, S.W. 1995: Hydrological and thermal response of lakes to climate: description and modeling. In: Lerman, A., Imboden, D. \& Gat, J. (eds): Physics and chemistry of lakes, 63-82. Berlin: Springer Verlag.

Magnuson, J.J. et al. 2000: Historical trends in lake and river ice cover in the Northern Hemisphere. Science 289, 1743-1746.

Overpeck, J.P. et al. 1997: Arctic environmental change of the last four centuries. Science 278, 1251-1256.

Serreze, M.C., Walsh, J.E., Chapin, F.S., Osterkamp, T., Dyurgerov, M., Romanovsky, V., Oechel, W.C., Morison, J., Zhang, T. \& Barry, R.G. 2000: Observational evidence of recent change in the northern high-latitude environment. Climatic Change $\mathbf{4 6}$, 159-207.

Vörösmarty, C.J., Hinzman, L.D., Petersen, B.J., Bronwich, D.H., Hamilton, L.C., Morison, J., Romanovsky, V.E., Sturm, M. \& Webb, R.S. 2001: The hydrological cycle and its role in Arctic and global environmental change: a rationale and strategy for synthesis study, 84 pp. Fairbanks, Alaska: Arctic Research Consortium of the U.S.

\section{Authors' addresses}

N.J.A., Geological Survey of Denmark and Greenland, Øster Voldgade 10, DK-1350 Copenhagen K, Denmark. E-mail: nja@geus.dk

S.C.F., Department of Geosciences, University of Nebraska, 214 Bessey Hall, Lincoln, NE 68588, USA.

C.E.G., Department of Agriculture and Rural Development, Agricultural and Environmental Science Division, Newforge Lane, Belfast BT9 5PX, UK

B.H., Institute of Geography, University of Copenhagen, Øster Voldgade 10, DK-1350 Copenhagen K, Denmark.

M.J.L., NERC Isotope Geoscience Laboratory, British Geological Survey, Keyworth, Nottingham, NG12 5 GG, UK. 